\title{
Short-term variability in pelagic-benthic exchange of phytopigments and their relations to benthic bacterial variables in the North Sea
}

\author{
Fleur C. van Duyl*, Gerard C. A. Duineveld, Arjen J. Kop \\ Netherlands Institute for Sea Research, PO Box 59, 1790 AB Den Burg, Texel, The Netherlands
}

\begin{abstract}
The short-term variability in pelagic-benthic exchange of phytopigments and the response of benthic bacteria to changes in phytopigment input in the bottom were studied in a temperature stratified water column including the sediment surface layer in the Oyster Grounds, North Sea, from 5 to 19 July 1994. The exchange of inorganic nutrients and phytopigments across the thermocline was limited during the cruise, with exception of a single short-lasting event on 14 July. This event resulted in enhancement of pigments throughout the water column and affected the pigment content in the surface mixed layer (SML) more and longer than in the benthic mixed layer (BML). The event did not result in a measurable change of sedimentation in the BML. The temporal variability of phytopigments in the SML was not reflected in the BML, where variations in phytopigments were determined by variations in tidal advection, sedimentation and resuspension. Variations in phytopigment fluxes to the bottom were demonstrated, with pigment sedimentation during slack tide exceeding sedimentation during full tide. The bulk of the phytodetrital material which settled during slack tide was resuspended during full tide. Nevertheless, there was net sedimentation of phytopigments, but insufficient to compensate for the decrease of the pigments in the sediment. The benthic phytopigment inventory gradually decreased during the cruise. Spatial variations in benthic phytopigments were significantly reflected by the spatial variations in bacterial variables, however the temporal decrease in algal pigments in the sediment was not reflected by the temporal variations in the benthic bacterial variables. Spatial relations between primary phytopigments and benthic bacterial production were decoupled in time implying that chlorophyll $a$ and fucoxanthin are poor indicators of the amount of bacterial substrate in the absence of fresh algal input (directly utilizable organic matter). The spatial relations between benthic bacterial variables and benthic phytopigments however indicate that the dominant source of food for bacteria in the Oyster Grounds is phytodetritus.
\end{abstract}

KEY WORDS: Pelagic-benthic exchange - Phytopigments - Benthic bacterial variables

\section{INTRODUCTION}

In shelf seas variability in algal biomass and its sedimentation is strongly influenced by meteorological and hydrodynamical circumstances. Meteorological forcing can change the water column structure and thus influence the primary productivity and the phytoplankton content in the water (e.g. Walsh et al. 1978, Hitchcock et al. 1987, Kiørboe \& Nielsen 1990, Ridderinkhof 1992, Kiørboe 1993, Tett \& Walne 1995). Vertical mixing

\footnotetext{
·E-mail: duyl@nioz.nl
}

events in temperature stratified shelf waters have been shown to trigger algal production and algal biomass increase and can be indirectly related to algal sedimentation (Noji et al. 1986, Olesen 1995). The signal of water column productivity is often received on the bottom and the pulses of pelagic food production can be rapidly incorporated into the sea floor (Suess 1980, Graf 1989, Ambrose \& Renaud 1995). Wave action and (tidal) currents may diminish settlement rates and can induce resuspension of particles from the bottom influencing the concentrations of phytodetritus in the water column (e.g. Jago et al. 1994). Lateral deposition fluxes have been reported to exceed vertical particle 
fluxes to the bottom (Graf 1992, Thomsen et al. 1995) Variations in phytodetritus from autochthonous and allochthonous sources in the water column determine the potential amounts available for deposition. Hydrodynamic conditions predominantly determine to what extent suspended organic matter will be deposited (e.g Creutzberg \& Postma 1979, Sündermann 1993). The synergistic effect of these different processes, which work at different time scales, contributes to short-term variations in algal matter in the water column and its deposition on the sediment.

Several studies have been dedicated to the response of benthic bacteria to the deposition of algae and phytodetritus (Meyer-Reil 1987, Graf 1992). Under manipulated conditions response rates have been shown to be fast when fresh algal material is concerned (e.g. Graf 1987. Turley \& Lochte 1990, van Duyl et al. 1992a, b). Little is known however of the response rate of bacteria to natural pulsed inputs in the field. Most studies roughly related benthic bacterial responses to large sedimentation events such as the spring and autumn algal bloom sedimentation in temperate regions (e.g. Graf et al. 1982, 1983, Meyer-Reil 1987, Pfannkuche 1993, Osinga et al. 1996). However the importance of small short-term sedimentation events of algal material for benthic bacteria activities and the bacterial response to such events is poorly known (Meyer-Reil 1987, van Duyl et al. 1993). Moreover limited attention has been paid to the time scales of exchange between variations in algal biomass, sedimentation/resuspension and benthic bacterial response under natural conditions (Graf 1992). If response rates are comparable to the rates found in experimental systems the spatial variations in benthic bacterial activities in the North Sea may be due to short-term temporal variations in algal sedimentation (van Duyl et al. 1993).

For exact determination of short-term variability in algal biomass, sedimentation and response rates of benthic bacteria in the North Sea, time scales of sampling have been insufficient until now. Such a study requires simultaneous and frequent sampling of physical, chemical and biological variables for several weeks at one station. Moreover it requires distinction between spatial and temporal variations of bottom variables in particular.

In the framework of the Integrated North Sea Programme we carried out such a sampling project (STED) at a temperature stratified station on the Oyster Grounds. The area represents a temporary depocentre in the North Sea (Puls \& Sündermann 1990, van Raaphorst et al. 1997) with large summer, seasonal and annual variations in the turnover of organic matter and in benthic bacterial activities (van Duyl \& Kop 1994, Osinga et al. 1996). At this station permanent moorings with measuring equipment registered from 1991 until
1995 the short-term variations in among others temperature, current velocities and fluorescence (van Haren 1993). During summers distinct short-term variations in fluorescence and algal biomass have been observed here (van Haren 1993, Ruardij et al. 1997).

We investigated the variability of phytopigments in the water column, their sedimentation and concentrations in the sediment, and the response of benthic bacteria. Algal pigments were determined, as they have been shown to be good indicators of labile compounds regulating sediment bacterial production and abundance (e.g. Bird \& Kalff 1984, Cole et al. 1988, Sander \& Kalff 1993, van Duyl \& Kop 1994). The aim of the study was to increase the understanding of the coupling between short-term (hours, days, weeks) variations in phytopigments in the water column and in the sediment and of the relation between shortterm benthic pigment variations and benthic bacterial variables.

The following questions were addressed: (1) To what extent is short-term variability in water column algal pigment concentrations in the North Sea reflected by variations in pigment sedimentation and pigment concentrations in the sediment surface layer? (2) Are benthic bacteria in numbers and production related to short-term variations in pigment concentrations in the sediment, and in pigment sedimentation?

\section{MATERIAL AND METHODS}

Study area. The study area was located on the Oyster Grounds in the North Sea (Fig. 1). This area is representative of the southern part of the central North Sea. The size of the study area was approximately $900 \times 900 \mathrm{~m}$. Water depth is $46 \mathrm{~m}$ and the water column was temperature stratified with a thermocline around 25 to $27 \mathrm{~m}$ depth. All samples were collected between 5 and 19 July 1994 aboard the RV 'Pelagia'.

A geographic scheme of the organization of the sampling area is given in Fig. 2. The dashed line surrounds the mooring site of ca $600 \times 600 \mathrm{~m}$ with moored instruments. The area is marked by 4 conspicuous buoys ( $R 1$ to R4) to warn ships. Along the north and east side of the mooring a grid of 17 sampling stations is indicated. The distance between stations was based on the need to have 17 non-overlapping anchor stations for the RV to eliminate sampling in sediments either disturbed by benthic sampling or by anchoring. Sediment remains after sampling were retained on board and discharged several nautical miles outside the study area. The study area was kept as small as possible to minimize the horizontal spatial variability of water column characteristics and of benthic variables. Moreover the spatial variability in the benthic compartment was 


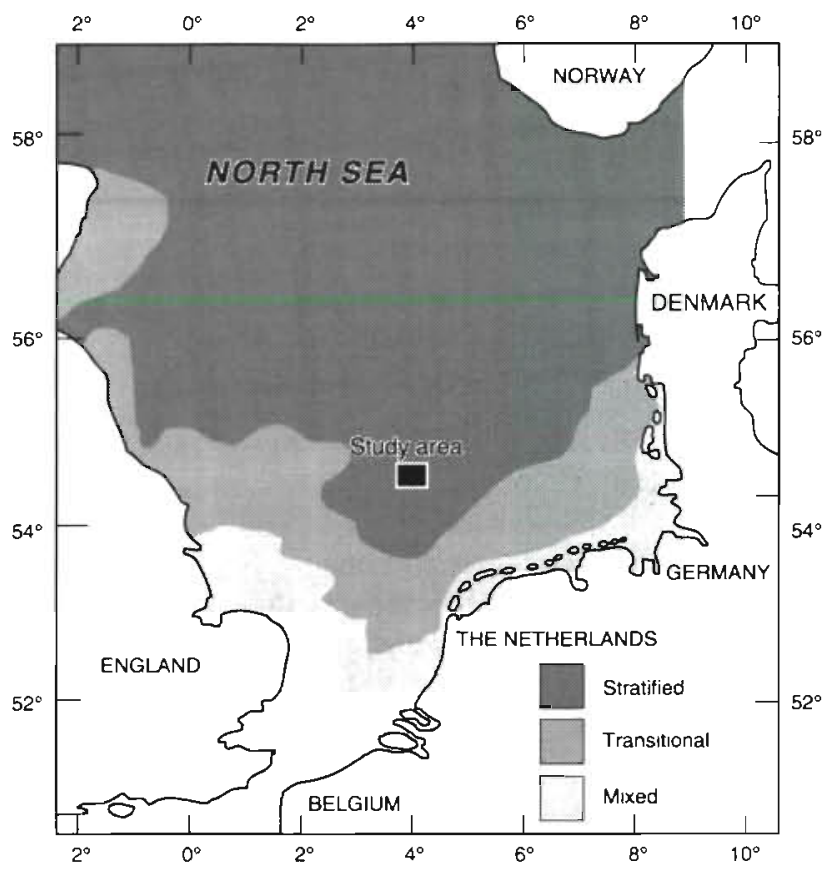

Fig. 1. Location of the study site in summer temperature stratified waters on the Oyster Grounds, North Sea

assessed to be able to distinguish between spatial and temporal variability.

Sampling methods and frequency. Semi-permanent moorings measured meteorological (e.g. wind force and direction, wave height), physical (e.g. temperature, currents), chemical (salinity) and biological (e.g. fluorescence) variables over the water column in the study area (van Haren 1993). Data used in this study comprised wind speed, wave height, temperature throughout the entire water column, fluorescence at 13 and $38 \mathrm{~m}$ depth, and current velocities and direction at $1.5 \mathrm{~m}$ above the bottom.

The sedimentation/resuspension of phytodetritus and organic matter (particulate organic carbon, POC) was determined in cylindrical Technicap multi-sample sediment traps (aspect ratio 120/25) located $3.5 \mathrm{~m}$ above the bottom at the mooring site (Fig. 2). One trap was programmed to collect phytodetritus during daytime for $2 \mathrm{~h}$ around slack tide and $2 \mathrm{~h}$ around full tide. Full tide is defined as the period with the highest current velocities during the tidal cycle, which occur on average $3 \mathrm{~h}$ before (in the ebb tide) or $3 \mathrm{~h}$ after LW (low water) slack tide (in the flood tide). Material collected in periods between full tide and slack tide was trapped as well to estimate daily sedimentation/resuspension. Organic matter for POC was collected in another trap, programmed to collect material every hour during nighttime (19:00 to 07:00 h next day) (van Raaphorst et al. 1997). Traps were emptied once a day between 08:00 and 09:00 h.
The water column and the sediment surface were sampled twice a day for approximately 45 min during slack tide and $45 \mathrm{~min}$ during full tide. In principle daily sampling occurred in one of the 17 sampling stations with the research vessel anchored in the middle of the station (GPS navigation). All samples were taken within the boundary of the station (see circles in Fig. 2). The sequence in which the stations were sampled from day to day was random.

Twice every day phytodetritus was sampled with a CTD-Rosette sampler at 5 and $40 \mathrm{~m}$ depth. Phytodetritus samples from just below the thermocline between 22 and $30 \mathrm{~m}$ depth were collected every other day in different tidal phases (slack and full tide). Every other day dissolved inorganic nutrients and POC were sampled at 6 different depths $(5,15,25,35,40$ and $45 \mathrm{~m})$ 2 times a day, once around slack tide and once during full tide. Inorganic nutrients $\left(\mathrm{NH}_{4}, \mathrm{NO}_{3}, \mathrm{PO}_{4}, \mathrm{SiO}_{2}\right)$ were determined on autoanalysers (Traacs). POC was determined on an HCN analyser (Verardo et al. 1990). Bottom water was collected from $20 \mathrm{~cm}$ above the bottom (0.2 mab, meters above bottom) by means of a membrane pump. Bottom water was sampled for bacterioplankton production on 6 days during the cruise. Intact sediment cores were collected with a cylindrical stainless-steel boxcorer (i.d. $30 \mathrm{~cm}$ ) and sampled for benthic phytopigments and bacterial variables. Each day 6 sediment boxcores were collected at 1 particular station number, i.e. 3 around slack tide and 3 around full tide. The spatial variance within each station was determined

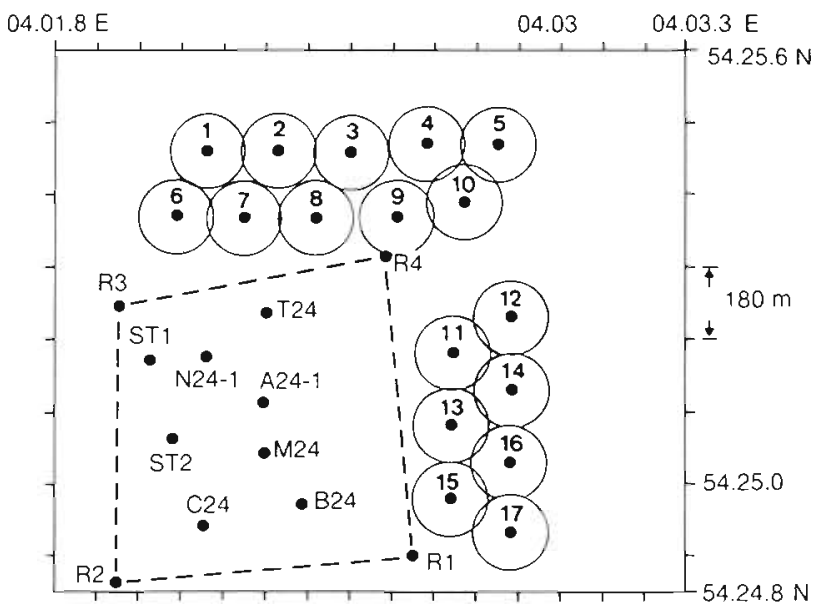

Fig. 2. Detail of the study area (ca $900 \times 900 \mathrm{~m}$ ) with a mooring site with equipment (ST: sediment traps; T: thermistorstring; B: fluorescence; A: acoustic doppler current profiler; $\mathrm{M}$ : meteorology station; $\mathrm{C}$ : current meters; $\mathrm{N}$ : nitrate autoanalysing system) in the SW part (ca $600 \times 600 \mathrm{~m}$, with R1 to $\mathrm{R} 4$ outline) and bordered on the $\mathrm{N}$ and $\mathrm{E}$ sides by 17 stations with a diameter of $180 \mathrm{~m}$ representing the daily stations for water and sediment sampling 
Spatial heterogeneity of the different sediment variables in the study area was determined by collecting 9 sediment boxcores within $2 \mathrm{~h}$ in 9 randomly selected stations of the 17 predetermined stations and directly subsampling for different analyses. This exercise was performed 2 times, once around slack tide ( 7 July) and once during full tide ( 9 July). Variance between sampling stations was determined.

Statistical analyses. To distinguish changes in time (every day another station was sampled) from spatial variability in the sediment variables, the spatial variance between stations was compared with the residual variance, which was based on changes of variables in time (days) during the cruise (Sokal \& Rohlf 1981). The heterogeneity sampling exercise provided data to estimate the spatial variation in the study area. Considering the fact that every station was sampled only once during this exercise the obtained variance encompassed the variance between stations as well as within stations. To estimate the spatial variance within stations, 14 different stations were sampled in 3 to 6 replicate boxcores on consecutive days. Subtracting the spatial variance in the study area from the variance within stations produces the spatial variance between stations. When the residual variance of the time series was of the same order of magnitude as the variance between stations and autocorrelation was absent, (multiple) regressions were applied to assess significant changes in time.

In addition paired observations of different variables were tested on relations with $t$-tests and 1-way ANOVAs (Sokal \& Rohlf 1981).

Measurements of phytopigments and bacteria. Phytopigments: Concentrations of the phytopigments chlorophyll a (CH) and fucoxanthin (FU) and its degradation product pheophytin a (PH) were determined in the water column, in the material collected in the sediment traps and in the sediment. PH was selected because it is an important early product of fresh $\mathrm{CH}$ degradation in the sediment and it is mainly formed through direct extracellular enzymatic activity by bacteria (Sun et al. 1993a and references therein). For qualitative analysis of the algal species composition in the water column additional pigments were analysed such as peridinin, zeaxanthin and chlorophyll $b, c 2$ and $c 3$. Water samples for pigments were filtered over $\mathrm{GF} / \mathrm{F}$ (Whatman filters, $47 \mathrm{~mm}$ diameter). After filtration filters were transferred to plastic tubes with stoppers, rapidly frozen in liquid nitrogen and stored in a $-80^{\circ} \mathrm{C}$ freezer until processing. Sediment samples were obtained by subsampling each sediment boxcore with 10 acrylic liners (i.d. $2.5 \mathrm{~cm}$ ). The upper $3 \mathrm{~mm} \mathrm{sec-}$ tion of the sediment cores was collected and pooled. Sediment slurries were made by adding $10 \mathrm{~cm}^{3}$ wet sediment to $10 \mathrm{~cm}^{3}$ filter sterilized seawater from the overlying water of the boxcore. Slurries were kept at field temperature and were subsampled for phytopigments, bacterial production and bacterial abundance within $2 \mathrm{~h}$. Sediment slurry samples of $5 \mathrm{~cm}^{3}$ for pigment analyses were pipetted with a cut-off pipette in plastic tubes with stoppers and treated similarly before storage as pigments concentrated on filters. Sediment slurry samples were also rapidly frozen and stored in liquid nitrogen. Before analysis these samples were freeze-dried. All pigment samples were analysed on a reverse-phase high-performance liquid chromatograph (RP-HPLC, Waters Associate) equipped with a RoSil C18 column and a Model 991 Water photo-diodearray spectrophotometer (for further details see Kraay et al. 1992, Boon \& Duineveld 1996). Sediment dry weight was $2.65 \mathrm{~g} \mathrm{~cm}^{-3}$ and porosity of the sediment surface layer was on the average $0.52(\mathrm{v} / \mathrm{v})(\mathrm{e} . \mathrm{g}$. van Raaphorst et al. unpubl.).

Bacterial production: Bacterial production was determined with $\mathrm{L}-\left[4,5-{ }^{3} \mathrm{H}\right]$ leucine with a specific activity of $164 \mathrm{Ci} \mathrm{mmol}^{-1}$ (Amersham) following Simon \& Azam (1989) for measurements in the water column and van Duyl \& Kop (1994) for measurements in sediment. For benthic bacterial production $200 \mu \mathrm{l}$ sediment slurry (see above) was incubated for $1 \mathrm{~h}$ with $27 \mu \mathrm{l}$ leucine solution (containing $0.02 \mathrm{nmol}{ }^{3} \mathrm{H}$-leucine and $0.18 \mathrm{nmol}$ leucine). Isotopic dilution was determined routinely in duplicate by adding $0.2,0.4$ or $0.6 \mathrm{nmol}$ leucine, each containing a fixed amount of labelled leucine $(0.02 \mathrm{nmol})$, to $200 \mathrm{\mu l}$ subsamples of sediment slurry (for method see Moriarty \& Pollard 1981). Isotopic dilution ranged from 0.23 to $0.77 \mathrm{nmol}$ in $200 \mu \mathrm{l}$ sediment slurry.

Bacterioplankton production in bottom water $(0.2 \mathrm{mab})$ was performed on $20 \mathrm{ml}$ bottom water samples. After the incubation the sample was split in 2 subsamples of $10 \mathrm{ml}$ each and one was fractionated over $3 \mu \mathrm{m}$ filters. The incorporated leucine was determined in the unfiltered water sample and in the $10 \mathrm{ml}$ filtrate. The difference between incorporation in the unfiltered samples and in the filtrate was attributed to the leucine incorporation of bacteria attached to particles $>3 \mu \mathrm{m}$. Analyses were conducted in triplicate. A saturation curve for leucine was made $(5,10,20,30,40,60 \mathrm{nM})$ showing that $10 \mathrm{nM}$ leucine saturated the uptake system of bacteria. No corrections were made for internal isotopic dilution according to Simon \& Azam (1989).

Bacterial numbers: In each sediment slurry bacterial numbers were counted after staining with acridine orange (van Duyl \& Kop 1994). One $\mathrm{cm}^{3}$ slurry was fixed with $50 \mu \mathrm{l}$ buffered $37 \% 0.2 \mu \mathrm{m}$ filtered formaldehyde. Slides for total counts were prepared the same day and stored at $-80^{\circ} \mathrm{C}$ until analyses. Fixed slurries were stored at $4^{\circ} \mathrm{C}$ and used for later preparations of slides for repetitive counting of bacteria. 
Fig. 3. Vertical temperature distribution during the cruise (isotherms of 9 to $19^{\circ} \mathrm{C}, 1^{\circ} \mathrm{C}$ )

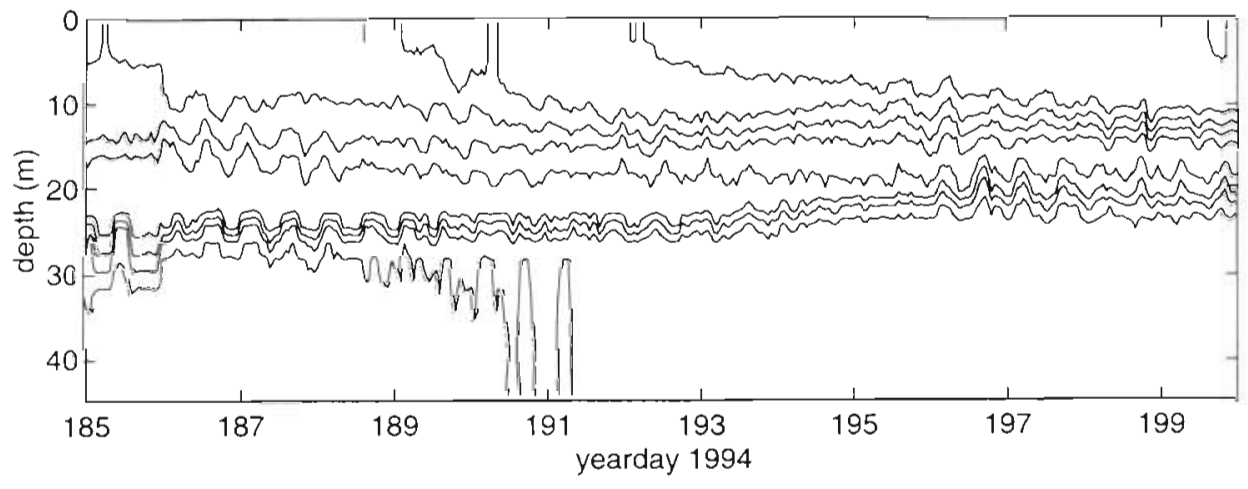

\section{RESULTS}

\section{Physical and chemical characteristics}

The weather was extremely calm during the expedition on the Oyster Grounds. Wind velocities varied between 0 and $8 \mathrm{~m} \mathrm{~s}^{-1}$ with a few short increases to $10 \mathrm{~m} \mathrm{~s}^{-1}$. Wave heights did not exceed $1 \mathrm{~m}$ and were usually less than $50 \mathrm{~cm}$.

The study site was temperature stratified with the thermocline initially around $27 \mathrm{~m}$ depth and gradually moving upwards in the course of time to $23 \mathrm{~m}$ depth (Fig. 3). In the surface mixed layer (SML: 0 to $10 / 15 \mathrm{~m}$ ) at $5 \mathrm{~m}$ depth temperature rose from 15 to $17.8^{\circ} \mathrm{C}$ and in the bottom mixed layer (BML: 25 to $46 \mathrm{~m}$ ) at $40 \mathrm{~m}$ depth from 8.5 to $9.6^{\circ} \mathrm{C}$ during the cruise. There was a 10 to $15 \mathrm{~m}$ thick non-turbulent intermediate water layer present during the cruise, extending from 10/15 to $25 \mathrm{~m}$ depth. During the cruise gradients in temperature became steeper in this water layer and it narrowed down to a thickness of $10 \mathrm{~m}$. Light penetrated in the entire water column with a maximal PAR of ca $10 \mu \mathrm{E}$ $\mathrm{m}^{-2} \mathrm{~s}^{-1}$ close to the bottom (van Haren et al. unpubl.).

The water column was characterized by nutrientpoor surface waters and slightly nutrient-enhanced bottom waters (Fig. 4). From 8 to 10 July (Days 188 to 190) increases in DIN, $\mathrm{PO}_{4}$ and $\mathrm{SiO}_{2}$ were observed in the water column, followed by decreases from 10 to 12 or 14 July (Days 190, 192, 194). From 14 to 16 July (Days 194 to 196) a slight increase in DIN (dissolved inorganic nitrogen), $\mathrm{PO}_{4}$ and $\mathrm{SiO}_{2}$ was recorded at $25 \mathrm{~m}$ depth. The $\mathrm{PO}_{4}$ increase was traced into the SML.

Current velocities ranged between 1 and $26 \mathrm{~cm} \mathrm{~s}^{-1}$ at $1.5 \mathrm{mab}$. The highest current velocities were measured between 9 and 11 July (Days 189 to 191), which were related to spring tide ( 8 July). Current speeds during sampling around slack tide (high water, HW, or LW) ranged from 1 to $8.7 \mathrm{~cm} \mathrm{~s}^{-1}$ and during full tide (ebb or flood tide) from 13.2 to $26 \mathrm{~cm} \mathrm{~s}^{-1}$, with the smallest amplitude of current velocities on 17 to 18 July after neap tide (15 July). The highest current velocities during sampling were measured around $290^{\circ}$ (WNW
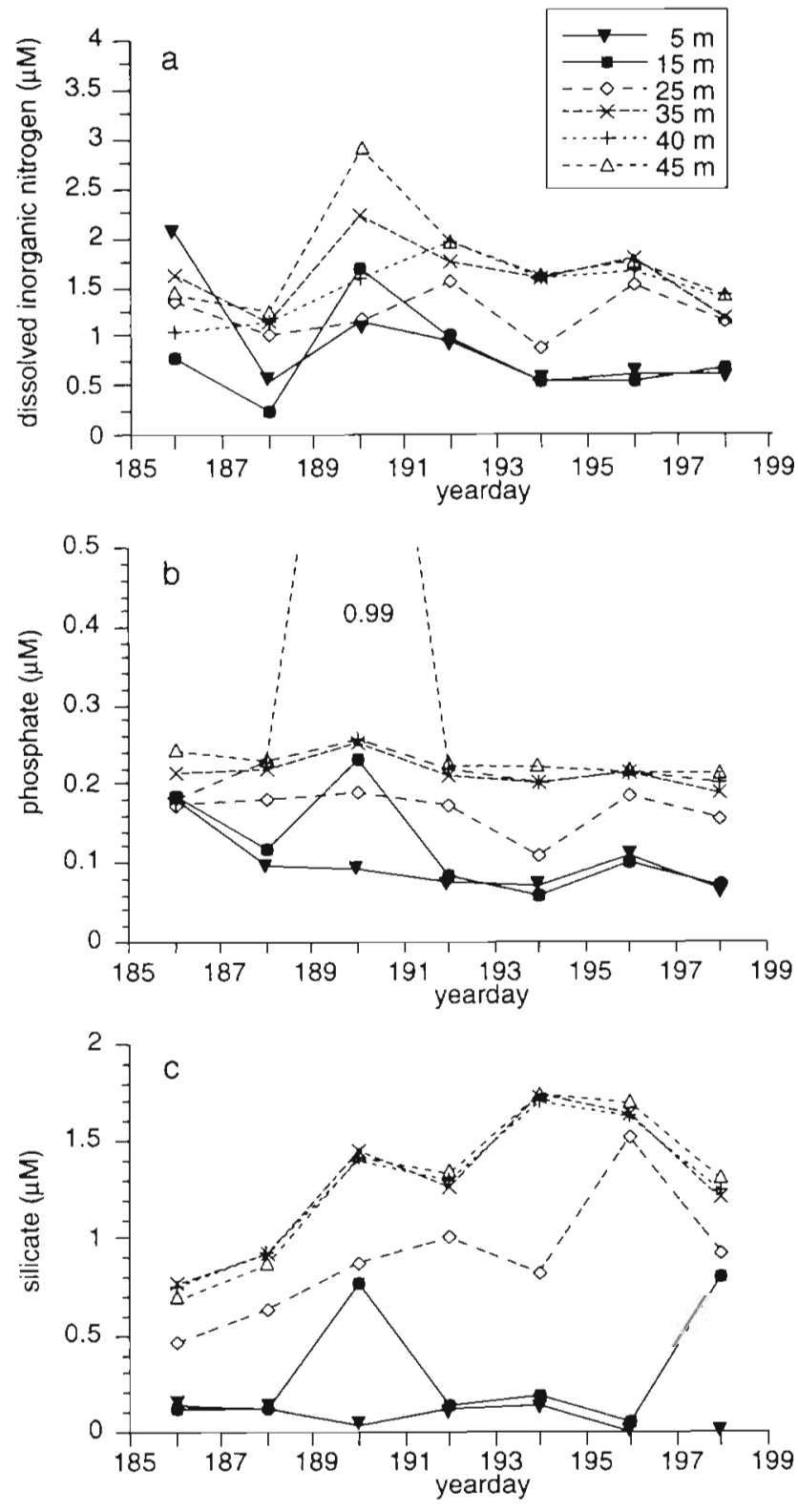

Fig. 4. DIN, $\mathrm{PO}_{4}$ and $\mathrm{SiO}_{2}$ concentrations at different depths during the cruise 
direction, ebb stream) and around $90^{\circ}$ (E direction, flood stream). Around slack tide current direction during sampling was variable.

\section{Phytopigments in the water column}

$\mathrm{CH}$ in the water column ranged from 100 to $400 \mathrm{ng}$ $\mathrm{I}^{-1}$ in the SML at $5 \mathrm{~m}$ depth and from 550 to $1400 \mathrm{ng} \mathrm{I}^{-1}$ in the BML at 25 and $40 \mathrm{~m}$ depth. These data were used to calibrate the fluorescence measurements of the fluorometers deployed at 13 and $38 \mathrm{~m}$ depth. Variations in fluorescence were related to the daily cycle in the SML, and roughly to the tidal cycle in the BML (Fig. 5a, b). Peaks in fluorescence in the BML appeared after the onset of the flood current until the decrease of the ebb current. During HW slack tide fluorescence usually remained high. Lowest fluorescence usually occurred during LW slack tide. This pattcrn was evident from Day 185 to Day 196. From Day 196 onwards to the end of the cruise (Day 200) the day-night cycle dominated the tidal cycle in the BML. Fluctuations and concentrations of $\mathrm{CH}$ in the BML decreased from 14 July (Day 194) onwards.

Fucoxanthin (FU) in the water column showed comparable variations to $\mathrm{CH}$, but its concentration was significantly lower (Fig. 5c). The ratios between FU and $\mathrm{CH}$ were significantly different in the SML and BML with a significant proportionate increase in $F U$ compared to $\mathrm{CH}$ in the BML [Fig. 6; compare $-(5 \mathrm{~m})$ with $\diamond(40 \mathrm{~m})$. Zeaxanthin was the dominant carotenoid in the SML (25 to $65 \mathrm{ng} \mathrm{l}^{-1}$ ) and was virtually absent in the BML. Peridinin was usually absent in the SML but well represented in the BML (20 to $40 \mathrm{ng} \mathrm{l}^{-\mathrm{t}}$ ). The chlorophyll $c 3 / c 2$ ratio was close to 1 in the $B M L$ and less than 1 in the SML.

There was a distinct increase in CH on 14 July in the SML (5 m depth, Day 194), which coincided with a small increase in nutrients (Fig. 5). The enhanced pigment content, fucoxanthin in particular, was traced throughout the water column. The $\mathrm{FU} / \mathrm{CH}$ ratio increased in the entire water column and other changes in pigment composition occurred in the SML (slight increase in chlorophyll $b$ in relation to $\mathrm{CH}$ ) and in the BML (peridinin slightly decreased and zeaxanthin slightly increased in the BML). The $\mathrm{PH}$ content was below the detection limit in the water column samples.

The POC content did not vary over the vertical and fluctuated between 100 and $400 \mu \mathrm{C} \mathrm{Cl}^{-1}$ (Fig. 7a). The POC content varied but did not significantly change in time except for a POC decrease in the BML from 6 to 10 July (Days 186 to 190 ). The $\mathrm{POC} / \mathrm{CH}$ ratio was significantly higher in the SML (POC/CH of ca 1000 at $5 \mathrm{~m}$ depth) than in the BML (POC/CH of $\mathrm{Ca} 200$ at 22 to $40 \mathrm{~m}$ depth).
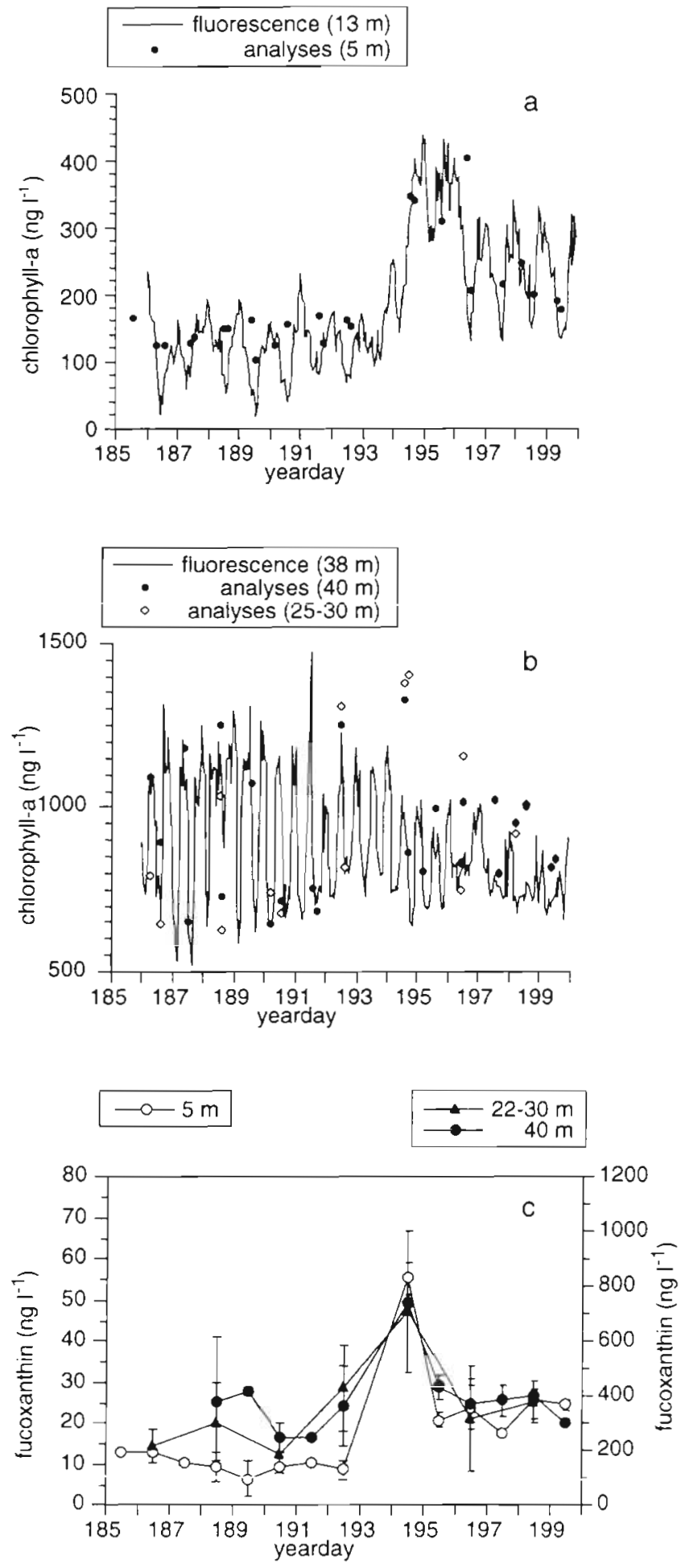

Fig. 5. (a) Chlorophyll a $(\mathrm{CH})$ variations in the SML: fluorescence at $13 \mathrm{~m}$ depth expressed as $\mathrm{CH}_{i}$ HPLC analyses of $\mathrm{CH}$ at $5 \mathrm{~m}$ depth. (b) $\mathrm{CH}$ variations in the $\mathrm{BML}$ : fluorescence at $38 \mathrm{~m}$ depth expressed in $\mathrm{CH}$; HPLC analyses of $\mathrm{CH}$ at 25 to 30 and at $40 \mathrm{~m}$ depth. (c) Fucoxanthin (FU) variations in the water column at $5 \mathrm{~m}$ depth in the SML and at 22 to 30 and $40 \mathrm{~m}$ depth in the BML 

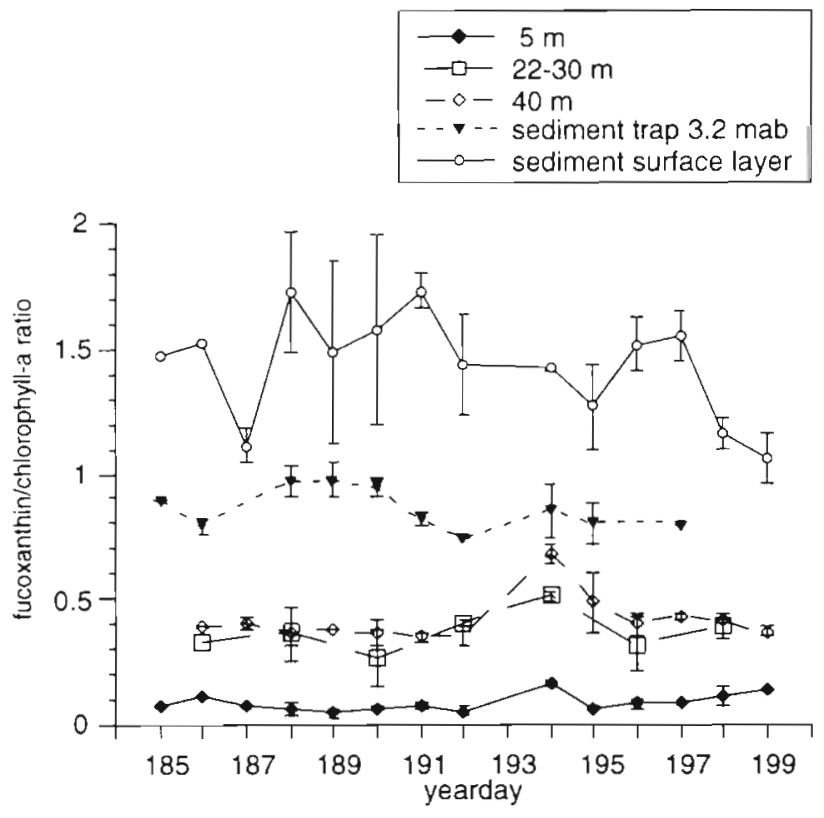

Fig. 6. FU/CH ratio at different depths in the water column, in the sediment trap and in the sediment surface layer

\section{Sediment trap results}

The trapping of phytodetritus in the BML was significantly greater around slack tide than during full tide ( $t$-test, df $=8, \mathrm{p}<0.01$ ) (Fig, 8a, b, c). During high water slack tide the pigment content in the BML was usually larger than during low water slack tide (see Fig. 5b), but this difference was not reflected in the sedimentation. The variations in average daily fluorescence $(\mathrm{CH})$ in the BML were significantly reflected by the sedimentation of $\mathrm{CH}$ and $\mathrm{FU}$ during slack tide (adjusted $\mathrm{R}^{2}=0.34, \mathrm{p}=0.05$ for $\mathrm{CH}$ and $\mathrm{R}^{2}=0.44, \mathrm{p}<0.05$ for FU). These relations were not found with sedimentation during full tide or with daily sedimentation of phytodetritus.

The highest sedimentation of $\mathrm{CH}$ was measured during low water slack tide on 8 July (Day 198), and was on the average $0.08 \mathrm{mg} \mathrm{CH} \mathrm{m} \mathrm{m}^{-2} 2 \mathrm{~h}^{-1}$. During full tide this was on the average $0.04 \mathrm{mg} \mathrm{CH} \mathrm{m}^{-2} 2 \mathrm{~h}^{-1}$. The daily accumulation of phytodetritus in traps ranged from 0.1 to 1.2 for $\mathrm{CH}$, from 0.1 to 0.8 for fucoxanthin and from 0.01 to $0.08 \mathrm{mg} \mathrm{m}^{-2} \mathrm{~d}^{-1}$ for $\mathrm{PH}$ (Fig. 8d). Daily POC accumulation in traps varied between 400 and $600 \mathrm{mg} \mathrm{C} \mathrm{m}{ }^{-2}$ (Fig. 7b). The enhanced phytopigment concentrations in the water column on 14 to 16 July (Days 194 to 196) were not reflected in the sedimentation pattern of phytopigments. From July 10 (Day 190) onwards the pigment accumulation in traps tended to decrease while the POC content remained stable (Figs. $7 \mathrm{~b} \& 8 \mathrm{c}$ ). The $\mathrm{FU} / \mathrm{CH}$ ratio in the traps was significantly higher than this ratio in the ambient water (Fig. 6). The POC/CH ratio of the sedimented material

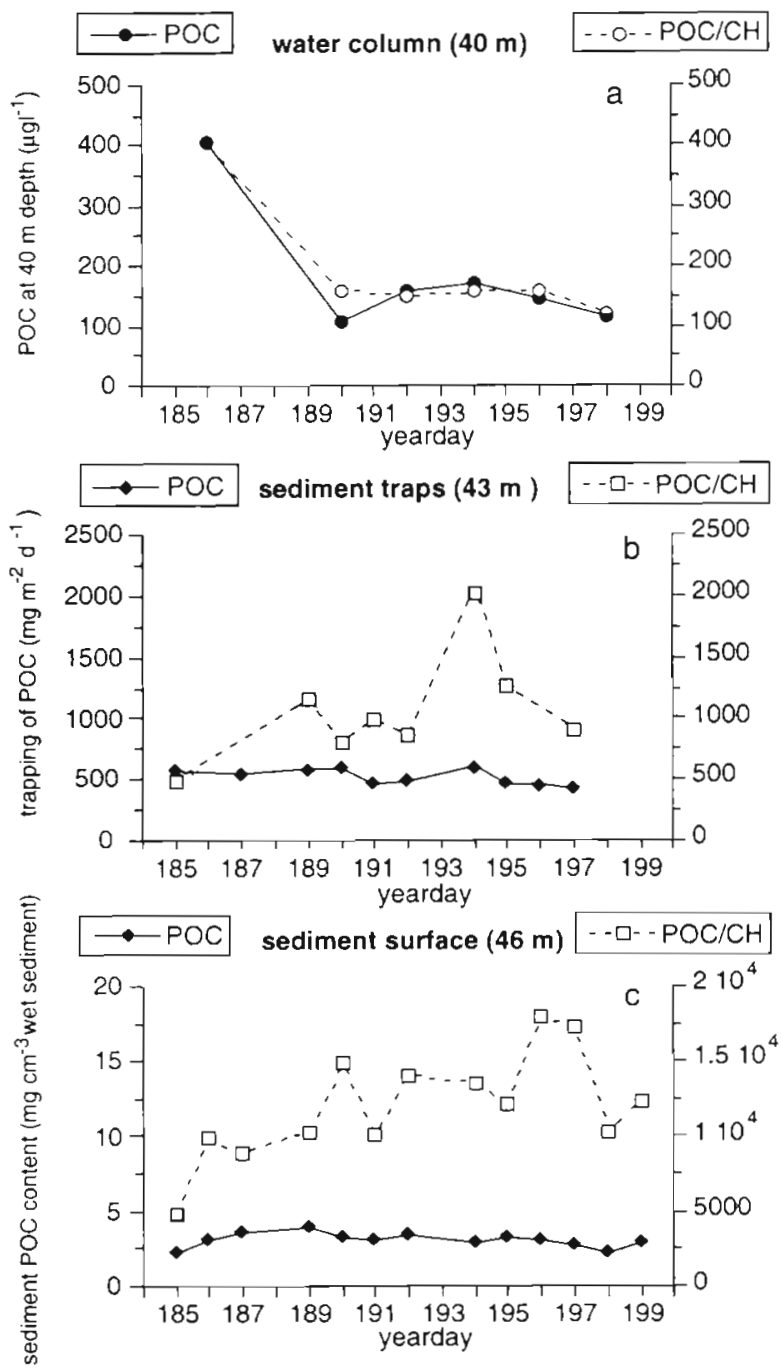

Fig. 7. Variations in the particulate organic carbon content (POC) and the POC/CH ratios in the (a) BML at $40 \mathrm{~m}$ depth, (b) sediment traps at $43 \mathrm{~m}$ depth and (c) sediment surface layer at $46 \mathrm{~m}$ depth

was also significantly higher than this ratio in the ambient BML water (Fig, 7a, b).

\section{Spatial heterogeneity}

There was a considerable spatial heterogeneity in benthic variables [phytopigment concentrations, bacterial production (BBP) and abundance (BBN)] in the study area (Table 1) despite the small distance between sampling sites (Fig. 2). The coefficients of variations for the benthic variables ranged from 28 to $41 \%$ for phytopigments, from 12 to $20 \%$ for BBN and from 20 to $38 \%$ for BBP. Spatial heterogeneity in benthic variables was less during high current velocities than during slack tide. 

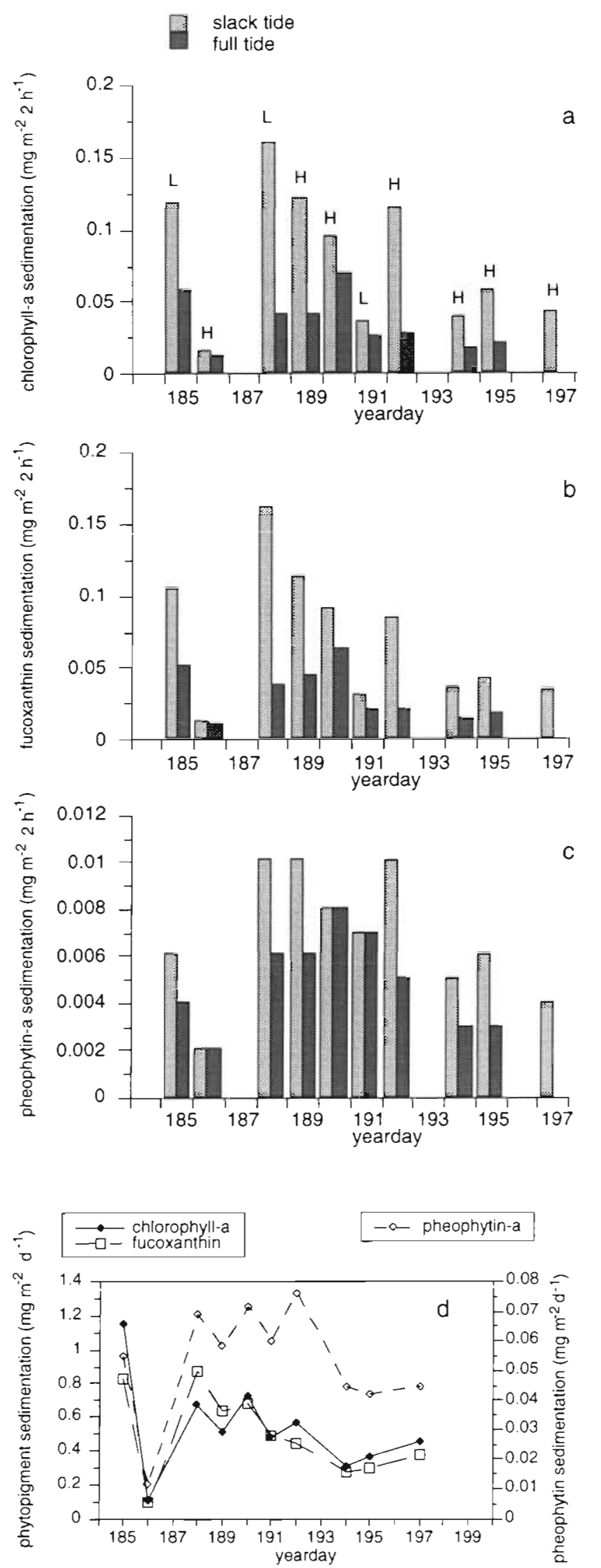

\section{Pelagic-benthic exchange in relation to tidal dynamics}

Despite the evident tidal periodicity in sedimentation there were no significant differences between the benthic data (BBN, BBP and phytopigments) collected during different tidal phases characterized by significantly different tidal currents, neither during the heterogeneity measurements (Table 1) nor during the daily measurements in slack and full tide periods ( $t$-test: $d f=11, p>0.3$ ).

However, the amount of FU trapped in different slack tide periods was positively related to the sediment FU content during slack tide periods ( 0 to $3 \mathrm{~mm}$; adjusted $\left.\mathrm{R}^{2}=0.25, \mathrm{p}<0.1\right)$. This relation was not found for data collected in full tides. For the samples collected in full tide only a significant inverse relation between the sedimentation of $\mathrm{PH}$ in traps and the sediment content of $\mathrm{PH}$ (adjusted $\mathrm{R}^{2}=0.56, \mathrm{p}<0.05$ ) was found.

Sedimentation of phytodetritus (CH, FU, Pri) during slack tide periods was positively related to the BBN and explained 32 to $58 \%$ of the variation in numbers $(p<0.1)$. In the BML average total counts of $0.4 \times 10^{6}$ bacteria $\mathrm{ml}^{-1}$ were determined, of which the part attached to sinking algal particles (not counted) may have settled on the sediment surface during slack tide. This temporal enrichment of the sediment by bacteria did not result in enhancement of BBP. The total bacterioplankton production in the BML ranged from 0.6 to $1.4 \mu \mathrm{g} \mathrm{C} \mathrm{l}^{-1} \mathrm{~d}^{-1}$ with approximately $45 \%$ of the bacterioplankton production in the fraction $>3 \mu \mathrm{m}$. The bacterioplankton production in the fraction $>3 \mu \mathrm{m}$ did not significantly vary in the tidal cycle $(t$-test, $d f=5, p>$ $0.5)$. Based on trap results it was estimated that the material with associated bacterioplankton production in the fraction $>3 \mu \mathrm{m}$ in approximately $45 \mathrm{I}$ of $\mathrm{BML}$ water may settle during $2 \mathrm{~h}$ around slack tide on $1 \mathrm{~m}^{2}$. This may enhance the BBP with approximately 15 to $30 \mu \mathrm{g} \mathrm{C} \mathrm{m}^{-2} \mathrm{~d}^{-1}$ during slack tide as compared to similar calculations during full tide. This enhancement is too low to result in a measurable increase in BBP in the upper $3 \mathrm{~mm}$ of the sediment.

\section{Pelagic-benthic exchange in relation to day-to-day variations in benthic variables}

The different phytopigments in the sediment showed a significant concentration decrease in time [adjusted

Fig. 8. Phytopigment sedimentation in the BML. Inventory of sedimentation of phytopigments in $2 \mathrm{~h}$ periods around high $(\mathrm{H})$ or low (L) water slack tide and in $2 \mathrm{~h}$ periods during full tide. (a) $\mathrm{CH}_{i}$ (b) $\mathrm{FU}_{i}$ (c) $\mathrm{PH}_{i}$ (d) daily sedimentation of $\mathrm{CH}, \mathrm{FU}$ and $\mathrm{PH}$ 
Table 1. Comparison of the spatial variability during slack tide and full tide for benthic variables (phytopigments, bacterial production and abundance) in the $3 \mathrm{~mm}$ sediment surface layer. There were no significant differences between data collected during slack or full tide (ANOVA). Averages and standard deviations are based on 9 observations. ns: not significant

\begin{tabular}{|c|c|c|c|c|}
\hline & Slack tide & Full tide & \multicolumn{2}{|c|}{$\mathrm{p}$} \\
\hline Date (July 1994) & 7 & 9 & & \\
\hline Sampling period (h:min) & $10: 05-11: 43$ & $14: 32-15: 59$ & & \\
\hline Current speed $\left(\mathrm{cm} \mathrm{s}^{-1)}\right.$ & $3.2 \pm 1.64$ & $20.18 \pm 1.63$ & & \\
\hline Current direction $\left(^{\circ}\right)$ & $126.53 \pm 123.09$ & $301.03 \pm 6.93$ & & \\
\hline \multicolumn{5}{|l|}{ Phytopigments } \\
\hline Chiorophyll a (mg m${ }^{-2}$ ) & $1.097 \pm 0.454$ & $0.950 \pm 0.270$ & 0.429 & ns \\
\hline Fucoxanthin $\left(\mathrm{mg} \mathrm{m}^{-2}\right)$ & $1.419 \pm 0.494$ & $1.245 \pm 0.443$ & 0.407 & ns \\
\hline Pheophytin $a\left(\mathrm{mg} \mathrm{m}^{-2}\right)$ & $0.358 \pm 0.138$ & $0.269 \pm 0.108$ & 0.148 & ns \\
\hline \multicolumn{5}{|l|}{ Bacteria } \\
\hline Bacterial numbers $\left(\mathrm{n} \mathrm{cm}^{-3}\right)$ & $2.4 \pm 0.5 \times 10^{9}$ & $2.4 \pm 0.3 \times 10^{9}$ & 0.854 & ns \\
\hline Bacterial production ( $\mathrm{mg} \mathrm{C} \mathrm{m}^{-2} \mathrm{~d}^{-1}$ ) & $30.8 \pm 11.8$ & $30.7 \pm 6.2$ & 0.972 & ns \\
\hline
\end{tabular}

$\mathrm{R}^{2}=0.30(\mathrm{CH}), \mathrm{R}^{2}=0.27(\mathrm{FU}), \mathrm{R}^{2}=0.26(\mathrm{PH}), \mathrm{n}=14$, $\mathrm{p}<0.04$ in all cases; Fig. 9a, b]. The disappearance of phytopigments in the sediment coincided with a slight decrease in phytodetritus concentrations in the water column (based on fluorescence; Fig, 5) and a slight decrease in sedimentation of phytopigments (Fig. 8). The POC concentrations did not show evident decreases during the cruise (Fig. 7). The $\mathrm{POC} / \mathrm{CH}$ ratio in the sediment traps and in the sediment increased over time. The input rate of phytopigments was less than the disappearance rate of phytopigments in the sediment. If the disappearance of phytopigments is solely attributed to decay of pigments, the first-order decay constants for pigments in the sediment would be $0.056 \mathrm{~d}^{-1}$ for $\mathrm{CH}$ (half-life $12 \mathrm{~d}$ ), $0.068 \mathrm{~d}^{-1}$ for FU (half-life $10 \mathrm{~d}$ ) and $0.055 \mathrm{~d}^{-1}$ for $\mathrm{PH}$ (half-life $13 \mathrm{~d}$ ).

The variations in daily sedimentation of $\mathrm{FU}$ were significantly reflected by its concentration in the sediment; $34 \%$ of the variation in the relation could be attributed to sedimentation (adjusted $\mathrm{R}^{2}=0.34, \mathrm{p}<$ $0.05)$. The FU/CH ratio in the sediment was significantly higher than the ratio in sediment traps and in the water column and varied between 1 and 2 (Fig. 6).

Significant day-to-day variations in BBP and BBN were not established. These variables did not exceed the spatial heterogeneity of the study area during the cruise (Fig. 10). So the decrease in phytopigments was not reflected by a decrease in the bacterial variables. The BBP and the BBN did not significantly change during the cruise and remained on average $32 \pm 8 \mathrm{mg} \mathrm{C} \mathrm{m}^{-2} \mathrm{~d}^{-1}$ and $2.5 \pm 0.3 \times 10^{9}$ bacteria $\mathrm{cm}^{-3}$ wet sediment respectively. Significant relations between $\mathrm{BBP}$ and $\mathrm{BBN}$ were absent. The rise in bottom temperature from 8.5 to $9.6^{\circ} \mathrm{C}$ during the cruise was not reflected by an increase in the $\mathrm{BBP}$ (Fig. 10a).
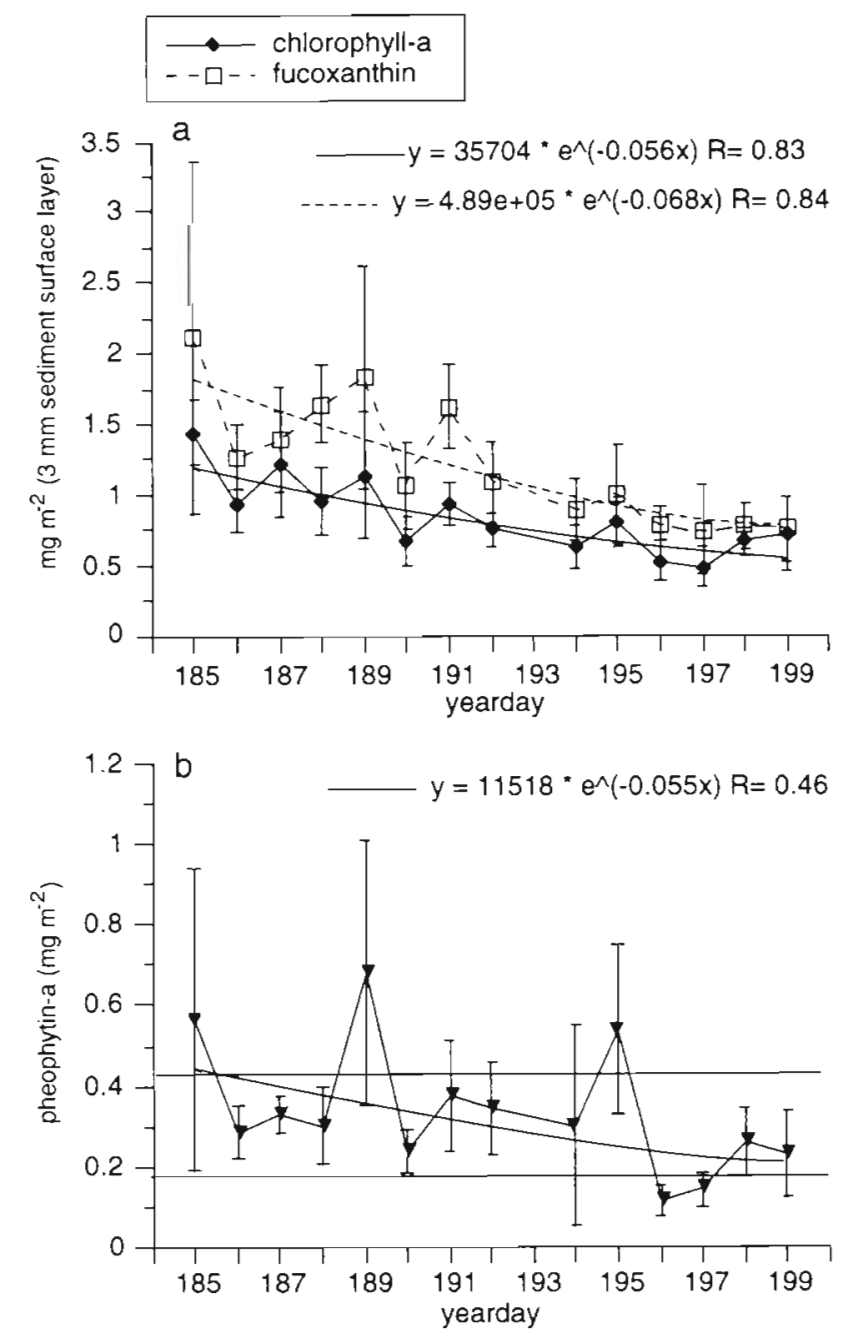

Fig. 9. Variations in benthic phytopigments in the $3 \mathrm{~mm}$ thick sediment surface layer for (a) $\mathrm{CH}$ and $\mathrm{FU}$ (spatial variability ranges from 0.7 to $1.4 \mathrm{mg} \mathrm{CH} \mathrm{m}{ }^{-2}$ and from 0.9 to $1.8 \mathrm{mg} F U$ $\mathrm{m}^{-2}$ ) and for (b) PH (spatial variability indicated) 

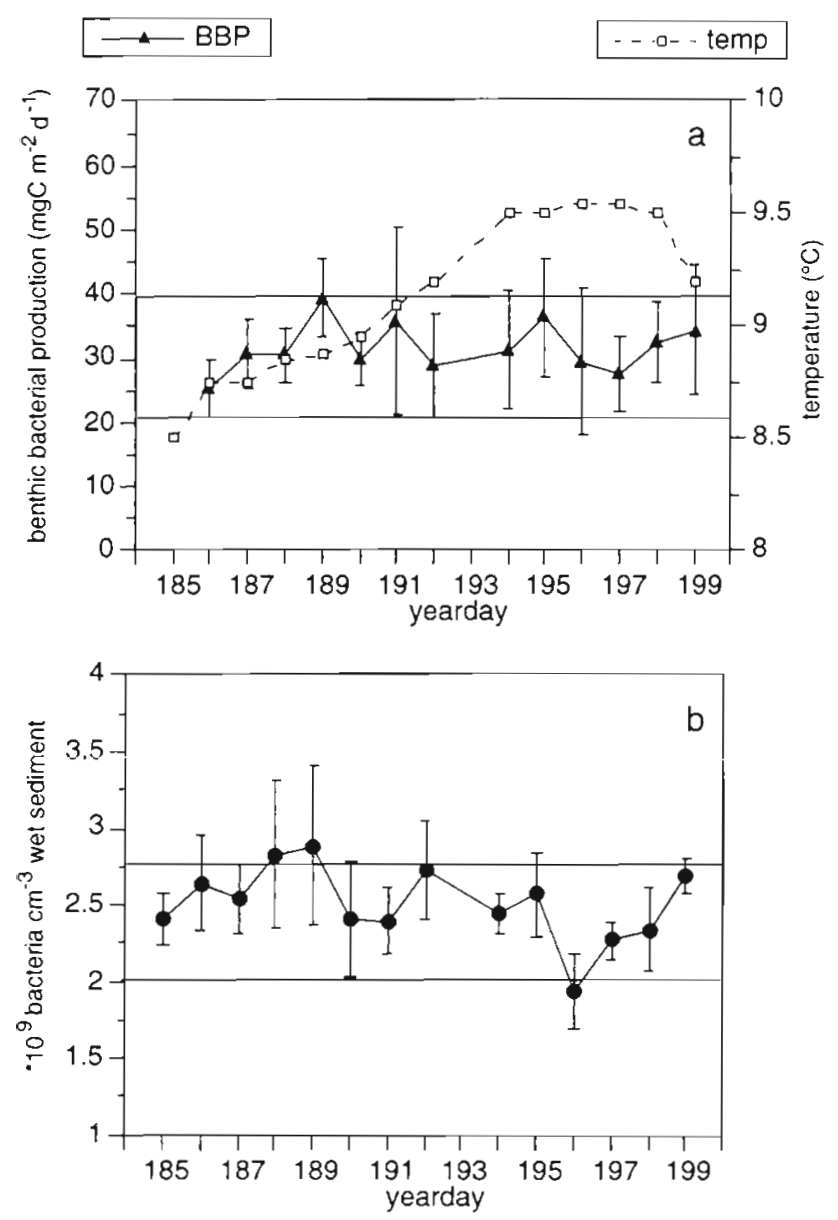

Fig. 10. Variations in (a) bacterial production and (b) bacterial abundance in the $3 \mathrm{~mm}$ thick sediment surface layer

\section{Relationships between bacterial variables and phytopigments in the sediment}

BBP (daily averages) was significantly correlated with the pigment concentrations (daily averages) of $\mathrm{PH}$ and the $\mathrm{PH} / \mathrm{CH}$ ratio in the sediment (adjusted $\mathrm{R}^{2}=$ $0.50,0.40, p<0.05)$. Significant correlations between $\mathrm{BBP}$ and benthic $\mathrm{CH}$ and $\mathrm{FU}$ respectively were absent. Only when time as well as benthic phytopigments were taken as independent variables in the multiple regression was 47 to $70 \%$ of the variation of $\mathrm{BBP}$ explained by variation in $\mathrm{CH}, \mathrm{FU}$ and $\mathrm{PH}$ ( $\mathrm{CH}$ : adjusted $\mathrm{R}^{2}=0.47 ;$ FU: $\left.\mathrm{R}^{2}=0.64, \mathrm{PH}: \mathrm{R}^{2}=0.70, \mathrm{n}=13, \mathrm{p}<0.05\right)$ Where the factor time was not involved such as in the heterogeneity sampling exercise, in which the variability of different variables is completely due to spatial heterogeneity, weakly significant relations were also found between BBP and the $\mathrm{FU}$ and $\mathrm{CH}$ phytopigment samples collected during full tide (adjusted $R^{2}=0.21$ to 0.32, $\mathrm{n}=9, \mathrm{p}<0.1$ ). During slack tide sampling this relationship was not found.
Variations in BBN (on basis of daily averages) were significantly correlated to the $\mathrm{PH}$ content of the sediment (adjusted $\mathrm{R}^{2}=0.23, \mathrm{n}=14, \mathrm{p}<0.05$ ). Relations between $B B N$ and the other benthic pigments were absent ( $p>0.1$ in all cases). When all BBN data of the time series ( 1 to 2 per day) were tested, 13 to $37 \%$ of the variations could be attributed to variations in phytopigments in the bottom $\left(\mathrm{CH}\right.$ : adjusted $\mathrm{R}^{2}=0.133, \mathrm{n}=$ $27, \mathrm{p}=0.035 ;$ FU: $\mathrm{R}^{2}=0.16, \mathrm{n}=27 \mathrm{p}=0.022 ; \mathrm{PH}: \mathrm{R}^{2}=$ $0.365, \mathrm{n}=27, \mathrm{p}=0.001$ ). No significant relations were found between BBN and benthic phytopigments in the samples collected for the determination of heterogeneity on 7 (slack tide) and 9 July (full tide).

\section{DISCUSSION}

The weather conditions were exceptionally calm and sunny throughout the cruise. In July small changes in the weather (cold front, summer storm) normally occur which induce small mixing events in the water column (Ridderinkhof 1992). This turbulence may extend to the depth of the thermocline and induce sufficient entrainment of the thermocline (Ruardij et al. 1997) to result in redistributions of nutrients and stimulation of algal growth and short-term increases of algal biomass. Substantially enhanced fluorescence occurred 2 wk before and just after the cruise (Fig. 11). During the STED cruise fluorescence was extremely low in the SML (summer minimum) with 1 minor increase in fluorescence.

\section{Water column phytopigment variability over time and depth}

Fluorescence and phytopigment concentrations showed short-term variations, which were largely coupled to day-night cycles of the phytoplankton in the SML and to tidal advection in the BML. Variations of phytopigments in the BML were quite large. Similar observations were made by Peeters et al. (1995). Such large variations appear to be mainly due to advective transport, which causes the semi-diurnal pattern with 2 major peaks in fluorescence, which build up during flood tide and drop off during ebo tide. Currents from the west to the east (predominantly flood streams) conveyed more phytopigments in the BML over the study area than ebb streams. This is in accordance with the spatial gradients in fluorescence in a more extended area around the station (van Raaphorst et al. 1997). Superimposed on this pattern, a different quarter-diurnal pattern occurred, related to resuspension and sedimentation of phytopigments. These patterns are in accordance with other observations in the North Sea (Jago et al. 1994). 

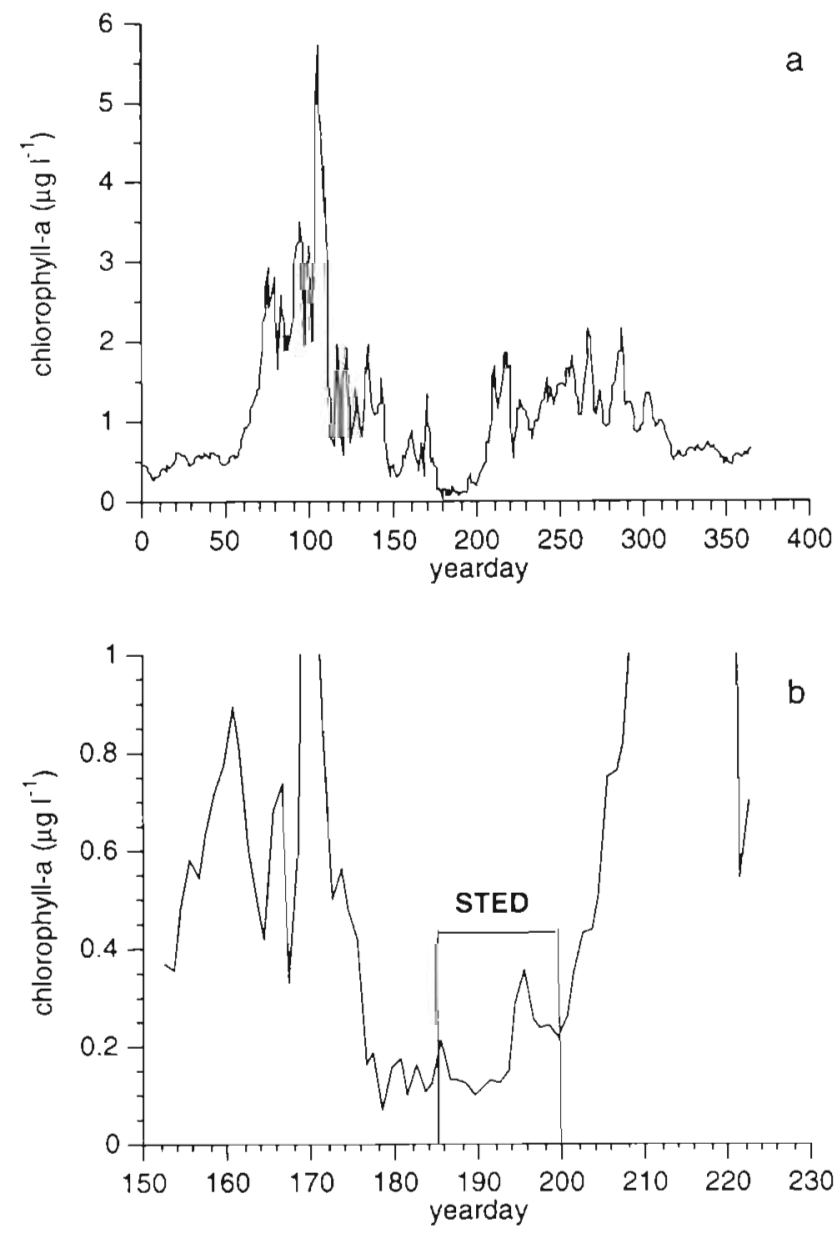

Fig. 11. (a) Seasonal fluorescence at $13 \mathrm{~m}$ depth in 1994, with (b) a detail of the period between Days 150 and 230, including the indicated STED cruise period

The increase in phytopigments on 14 July (Day 194) in the SML and the thermocline (25 $\mathrm{m}$ depth) coincided with/was preceded by a slight increase in $\mathrm{PO}_{4}$. Significant increases in inorganic $N$ were not established, but uptake by algae of these components, particularly $\mathrm{NH}_{4}$, may be very fast in summer (e.g. Le Corre et al. 1996). The observation that the FU concentration and the $\mathrm{FU} / \mathrm{CH}$ ratio were higher on this day than on previous days in the entire water column suggests that a mixing event took place, induced by internal waves creating shear stress between water masses in the thermocline. The sudden and short mixing event probably enhanced resuspension of phytodetritus in the BML and triggered some particle exchange between the BML and SML. It is unlikely that the increase in phytopigments in the SML was related to the increase in nutrients around $10 \mathrm{July}$ (Day 190); the time lag between the decrease in nutrients and the increase in fluorescence was too long (ca 4 d).
Further exchange of pigments and nutrients across the thermocline was limited. The strong stratification around $25 \mathrm{~m}$ depth and the temperature gradient in the SML on top of the thermocline (non-turbulent intermediate layer; Ruardij et al. 1997) were indicative of the limited vertical heat exchange, which kept the turbulent diffusion low during the cruise. The limited exchange resulted in persistent concentration differences in inorganic nutrients and phytopigments between the SML (100 to $400 \mathrm{ng} \mathrm{l}^{-1}$ ) and the BML (550 to $1400 \mathrm{ng} \mathrm{l}^{-1}$ ). Comparable differences between the SML and BML have been found in the North Sea in summer before, but our absolute values were considerably lower (e.g. Gieskes \& Kraay 1984, Peeters et al. 1995, Karlson et al. 1996). The inorganic nutrient concentrations were low enough (particularly $\mathrm{PO}_{4}$ ) to limit primary production in the SML. In the BML nutrient concentrations were almost 2 to 3 times higher than in the SML.

Another indication of limited exchange between water layers was the differences in pigment finger prints. The occurrence of zeaxanthin in the SML suggests the presence of cyanobacteria, prochlorophyta and green algae (see Wright et al. 1991). Considering the size of these small organisms it is unlikely that they sink into the BML, unless aggregates or fecal pellets are formed. The FU/CH ratio was significantly larger in the BML than in the SML. FU is an indicator of diatoms and prymnesiophytes (Jeffrey 1974). In combination with the found chlorophyll $c 3 / c 2$ ratio of about 1 and the fact that chlorophyll $c 3$ is generally absent in diatoms (Stauber \& Jeffrey 1988) it is most likely that prymnesiophytes such as Phaeocystis (Jeffrey \& Wright 1994) occurred in the BML. This pigment fingerprint is also characteristic for some dinophytes (see Jeffrey \& Wright 1994). In combination with peridinin, a major signature pigment for autotrophic dinoflagellates which is consistently present in the BML and absent in the SML, it is likely that these dinoflagellates are relatively abundant in the BML and absent in the SML. So it is most probable that completely different algal communities developed and persisted in the different water layers.

We conclude that the variability in phytopigments in the SML and the BML differed substantially. The flux of pigments across the SML-BML interface was limited, except for the event on 14 July, which resulted in a significant increase in pigments in the SML. There may have been a flux of aggregates and fecal pellets from the SML into the BML, but their contribution to phytopigment variability in the BML was probably small, considering the low concentrations of pigments in the SML and the temporal variations in pigments in the SML, which were generally not reflected by variations in the BML. Moreover recovery of pigment finger 
prints from fecal pellets is usually low. This implies that the pigment content and algal composition in the BML largely developed in the BML.

\section{Exchange of pigments in the BML and sedimentation}

The question addressed here is whether the phytopigment concentrations in the BML are related to the sedimentation of phytopigments.

The tidal variations in water column pigments in the BML were partly reflected by variations in pigment sedimentation. Decreases in fluorescence around slack tide usually coincided with increases in sedimentation compared to amounts trapped during full tide. Comparable tidal sedimentation patterns of $\mathrm{CH}$ were described by Jenness \& Duineveld (1985) in more turbulent areas in the North Sea. The observation that fluorescence was significantly higher at the onset of HW than at the onset of LW slack tide was not reflected in the amounts of phytopigments trapped. This suggests decoupling between concentrations in the water column and sedimentation of phytopigments in the tidal cycle. Algal sedimentation is not necessarily determined by algal density (Kiørboe \& Hansen 1993). Conditions for flocculation might have been more suitable around LW slack tide than around HW slack tide. Van Raaphorst et al. (1997) demonstrated that the total seston content is higher around LW than around HW slack tide. This may have stimulated flocculation and sedimentation of phytodetritus during LW slack tide compared to HW slack tide, which explains the comparable amounts of pigment sedimentation during low and high water slack tide. The close relation between daily average fluorescence $(\mathrm{CH})$ and primary pigment sedimentation during slack tide points to coupling between water column concentrations and sedimentation on a day-to-day basis. Moreover the day-to-day decrease of $\mathrm{CH}$ in the BML in the last week of the cruise coincided with a slight decrease in sedimentation.

So absence of coupling between concentration in the water column and sedimentation of phytopigments was observed on a tidal scale, but coupling on a daily/ weekly scale.

\section{Relations between pigment sedimentation and benthic variables}

The next question is: are tidal, day-to-day and weekly variations in phytopigment sedimentation reflected by variations in benthic phytopigments and bacteria? The significant differences between sedimentation during slack tide and full tide were not reflected by the phytopigment concentrations and the bacterial variables in the sediment surface layer. Although demonstrated in traps, tidal variations in settlement and resuspension of pigments, such as those established by Jenness \& Duineveld (1985) in the southern North Sea, were not found in the bottom on the Oyster Grounds. The sections of $3 \mathrm{~mm}$ of the sediment surface layer were probably too thick to show tidal variations of phytopigment concentrations in the sediment. The epibenthic fluffy material containing phytodetritus comprised only a small fraction (less than $500 \mu \mathrm{m}$ ) of the $3 \mathrm{~mm}$ thick sediment samples. This is probably why the benthic phytopigment and bacterial variables were not significantly higher during slack tide than during full tide. Only the standard deviations of the benthic variables were larger when measured during slack tide (Table 1). This indicates that phytodetritus and bacteria settled patchily on the bottom during slack tide, probably due to irrcgularitics of the bottom surface such as mounds, depressions and small holes created by benthic fauna.

Nevertheless some indications for exchange of phytopigments between the water phase and the bottom were found. FU and bacteria accumulated in slack tide periods, considering the positive relationships between FU sedimentation and its content in the sediment and the relationships between phytopigment sedimentation and benthic bacteria. Net sedimentation during slack tide must have been low, however, because accumulation could not be demonstrated for $\mathrm{CH}$ and accumulation of particle-associated bacteria did not result in measurable enhancement of the BBP. The inverse relationship between $\mathrm{PH}$ sedimentation and its content in the sediment during high current velocities suggests that resuspension of epibenthic phytodetrital matter, which was deposited during slack tide, occurs and that this results in disappearance of most of the phytodetrital material which settled during slack tide. On a daily basis sedimentation of phytodetritus on the sediment must have exceeded resuspension. The variations in fluorescence related to tidally induced advective transport indicate that there was a gradient with higher fluorescence on the $W$ side and lower fluorescence on the E side in a larger area encompassing the study area (van Raaphorst et al. 1997). This gradient persisted until Day 196 (Fig. 5b) implying that deposition exceeded resuspension of phytodetritus. Van Raaphorst et al. (1997) estimated a net average sedimentation of $115 \mathrm{mg}$ POC $\mathrm{m}^{-2} \mathrm{~d}^{-1}$ during the cruise. This complies with a net average $\mathrm{CH}$ sedimentation of $0.117 \mathrm{mg} \mathrm{CH} \mathrm{m}{ }^{-2} \mathrm{~d}^{-1}$, considering the average POC/ $\mathrm{CH}$ ratio in the sediment traps ( $w / w$ 985). This ratio was selected because trap material has actually settled under the hydrodynamic circumstances. Daily gross $\mathrm{CH}$ sedimentation in traps is on the average almost 5 
times larger than net $\mathrm{CH}$ sedimentation, indicating the overestimation of pigment sedimentation in traps. Variations in net pigment sedimentation were probably insufficient to induce variations in benthic variables. POC, BBP and BBN did not significantly change in the sediment and appeared to be in steady state while benthic phytopigments decreased. The input was apparently insufficient to compensate for the decrease in benthic phytopigments.

The FU/CH ratio of the material trapped during slack tide could not be distinguished from the ratio of the material trapped during full tide. The FU/CH ratio was significantly higher in traps than in surrounding water and lower than the ratio in sediment. This may imply that trapped particles are relatively rich in FU and comprise phytodetrital particles suspended from the bottom. The higher FU/CH ratio in the sediment surface may have been the result of diatom sedimentation events preceding our cruise (Ruardij et al. 1997). Diatoms are relatively richer in $\mathrm{FU}$ than in $\mathrm{CH}$ compared to most other algal groups (Jeffrey 1974, Jeffrey \& Wright 1994).

Benthic-pelagic exchange of phytopigments in the tidal cycle was assessed. Net sedimentation of phytodetritus occurred, but was under the circumstances too small and varied insufficiently to be reflected by the day-to-day and weekly variations in benthic variables.

\section{Relations between pigments and bacterial variables in the sediment}

The last questions are: why did the bacteria in the sediment surface layer not respond to the variations in benthic phytopigments and what is the nature of the relations between benthic bacteria and phytopigments?

Algal pigments, such as $\mathrm{CH}$ and pheopigments, have been shown to be indicators of available food for bacteria and significant relations between the variables are usually found (e.g. Cole et al. 1988, Sander \& Kalff 1993, van Duyl \& Kop 1994). Most of these studies refer to spatial variability based on a wide range of sediment types. $\mathrm{CH}$ and pheopigments in North Sea sediments usually covary with bacterial biomass and benthic pheopigment content is a good predictor of BBP beside temperature (van Duyl \& Kop 1994).

In the present study the significant decreases in benthic phytopigments were however not reflected by benthic bacterial variables. The temporal variations in $B B P$ and $B B N$ did not exceed the spatial variations and $\mathrm{BBP}$ and $\mathrm{BBN}$ remained equal for 2 wk. Apparently a decoupling of BBP and $\mathrm{CH}$ and FU as indicators of food availability occurred over time. The decrease in ben- thic phytopigments might be due to selective burial by mixing activities of macrofauna, but it is also likely that part of the decrease was due to decomposition/transformation reactions in situ. Pigment degradation following first-order kinetics resulted in decay rates, which were of the same order of magnitude as found by others (Leavitt \& Carpenter 1990, Abele-Oeschger 1991, Sun et al. 1993b). Contrary to $\mathrm{CH}$ and FU, PH and the $\mathrm{PH} / \mathrm{CH}$ ratio were significantly related to $\mathrm{BBP}$ and $B B N$ respectively. The temporal decrease of $\mathrm{PH}$ was apparently insufficient to mask its spatial relations with bacterial variables. This may be related to the observations that $\mathrm{CH}$ degradation to $\mathrm{PH}$ under oxic conditions is probably induced by microorganisms (Bianchi et al. 1988, Sun et al. 1993a), which may also point to a closer relation between bacterial variables and $\mathrm{PH}$ than with the other pigments.

It appears that the spatial relations between BBP and $\mathrm{CH}$ and $\mathrm{FU}$ in the sediment are masked by time, possibly by time passed since the last substantial algal sedimentation. This may imply that spatial relations between BBP and benthic $\mathrm{CH}$ and FU can always be found in an area with a comparable recent history of phytopigment input in the sediment surface. Only the ratio between $B B P$ and these pigments will increase with time passed since the last substantial phytodetritus sedimentation event. Apparently $\mathrm{CH}$ and FU are only markers of food availability but poor indicators of the amount of available food for bacteria. The degradation/disappearance rate of these pigments may be faster in the sediment than the decomposition of most of the phytogenic material they represent (including $\mathrm{PH}$ ). The relations between benthic bacterial variables and phytopigments imply that the dominant source of food for benthic bacteria in the Oyster Grounds is phytodetritus

Acknowledgements. We are grateful for the help of Ronald Osinga, Mathieu Starink, Jos Thieme, Henk Franken, Ruud Groenewegen, Evaline van Weerlee, Annette van Koutrik, Willem Polman and the crew of the RV 'Pelagia'. Gijs Kraay is thanked for his support with pigment analyses. Wim van Raaphorst and Hans van Haren are acknowledged for putting POC, nutrient, meteorological, current velocity, temperature and fluorescence data at our disposal. Jaap van der Meer is acknowledged for the statistical advice. We thank Wim van Raaphorst and Arjen Boon for critically reading the manuscript. This research was partly funded by BEON (grant 94/95 E-01) and by the Netherlands Marine Research Foundation (grant 39104). This is NIOZ publication no. 3176.

\section{LITERATURE CITED}

Abele-Oeschger D (1991) Potential of some carotenoids in two recent sediments of Kiel Bight as biogenic indicators of phytodetritus. Mar Ecol Prog Ser 70:83-92

Ambrose WG Jr, Renaud PE (1995) Benthic response to water column productivity patterns: evidence for benthic- 
pelagic coupling in the Northeast Polynya. J Geophys Res 100:4411-4421

Bianchi TS, Dawson R, Sawangwong P (1988) The effects of macrobenthic deposit-feeding on the degradation of chloropigments in sandy sediments. J Exp Mar Biol Ecol 122:243-255

Bird DF, Kalff J (1984) Empirical relationships between bacterial abundance and chlorophyll concentration in fresh and marine waters. Can J Fish Aquat Sci 41:1015-1023

Boon AR, Duineveld GCA (1996) Phytopigments and fatty acids as molecular markers for the quality of near-bottom particulate organic matter in the North Sea. J Sea Res 35 : 279-291

Cole JJ, Findlay S, Pace ML (1988) Bacterial production in fresh and saltwater ecosystems: a cross-system overview. Mar Ecol Prog Ser 43:1-10

Creutzberg F, Postma H (1979) An experimental approach to the distribution of mud in the southern North Sea. Neth J Sea Res 13:99-116

Gieskes WWC, Kraay GW (1984) Phytoplankton, its pigments, and primary production at a central North Sea station in May, July and September 1981. Neth J Sea Res 18:51-70

Grai $G$ (1987) Benthic energy flow during a simulated autumn bloom sedimentation. Mar Ecol Prog Ser 39:23-29

Graf G (1989) Benthic-pelagic coupling in a deep-sea benthic community. Nature 341:437-439

Graf G (1992) Benthic-pelagic coupling: a benthic review. In: Barnes M, Ansell AD, Gibson RN (eds) Oceanography and marine biology. UCL Press, London, p 149-190

Graf G, Bengtsson W, Diesner U, Schulz R, Theede H (1982) Benthic response to sedimentation of a spring phytoplankton bloom: process and budget. Mar Biol 67:201-208

Graf G, Schulz R, Peinert R, Meyer-Reil LA (1983) Benthic response to sedimentation events during autumn to spring at a shallow-water station in the western Kiel Bight. Mar Biol 77:235-246

Hitchcock GL, Langdon C, Smayda TJ (1987) Short-term changes in the biology of a Gulf Stream warm-core ring: phytoplankton biomass and productivity. Limnol Oceanogr 32:919-928

Jago CF, Bale AJ, Green O, Howarth MJ, Jones SE, McCave IN, Millward GE, Morris AW, Rowden AA, Williams JJ (1994) Resuspension processes and seston dynamics, southern North Sea. In: Charnock $H$, Dyer KR, Huthnance JM, Liss PS, Simpson JH, Tett PB (eds) Understanding the North Sea system. Chapman \& Hall, London, p 97-113

Jeffrey SW (1974) Profiles of photosynthetic pigments in the ocean using thin-layer chromatography. Mar Biol 26 : $101-110$

Jeffrey SW, Wright SW (1994) Photosynthetic pigments in the Haptophyta. In: Green JC, Leadbeater BSC (eds) The Haptophyte alga. Clarendon Press, Oxford, p 111-132

Jenness MI, Duineveld GCA (1985) Effects of tidal currents on chlorophyll a content of sandy sediments in the southern North Sea. Mar Ecol Prog Ser 21:283-287

Karlson B, Edler L, Granéli W, Sahlstein E, Kuylenstierna M (1996) Subsurface chlorophyll maxima in the Skagerrak processes and phytoplankton community structure. J Sea Res 35:139-158

Kiørboe T (1993) Turbulence, phytoplankton cell size, and the structure of pelagic food webs. In: Blaxter JHS, Southward AJ (eds) Advances in marine biology. Academic Press, London, p 1-72

Kiørboe T, Hansen JLS (1993) Phytoplankton aggregate formation: observations of patterns and mechanisms of cell sticking and the significance of exopolymeric material. J Plankton Res 15:993-1018
Kiørboe T, Nielsen TG (1990) Effects of wind stress on vertical water column structure phytoplankton growth and productivity of plankton copepods. In: Barnes M, Barnes RNG (eds) Trophic relationships in the marine environment. Univ Press, Aberdeen, p 28-40

Kraay GW, Zapata M, Veldhuis MJW (1992) Separation of chlorophylls $\mathrm{c} 1, \mathrm{c} 2$ and $\mathrm{c} 3$ of marine phytoplankton by reverse-phase-C18-high-performance liquid chromatography. J Phycol 28:708-712

Leavitt PR, Carpenter SR (1990) Aphotic pigment degradation in the hypolimnion: implications for sedimentation studies and paleolimnology. Limnol Oceanogr 35:520-534

Le Corre P, Wafar M, L'Helguen S, Maguer JF (1996) Ammonium assimilation and regeneration by size-fractionated plankton in permanently well-mixed temperature waters. J Plankton Res 18:355-370

Meyer-Reil LA (1987) Seasonal and spatial distribution of extracellular enzymatic activities and microbial incorporation of dissolved organic substrates in marine sediments Appl Environ Microbiol 53:1748-1755

Moriarty DJW, Pollard PC (1981) DNA synthesis as a measure of bacterial productivity in seagrass sediments. Mar Ecol Prog Ser 5:151-156

Noji T, Passow U, Smetacek V (1986) Interaction between pelagial and benthial during autumn in Kiel Bight. I. Development and sedimentation of phytoplankton blooms Ophelia 26:333-349

Olesen M (1995) Comparison of the sedimentation of a diatom spring bloom and of a subsurface chlorophyll maximum. Mar Biol 121:541-547

Osinga R, Kop AJ, Duineveld GCA, Prins RA, van Duyl FC (1996) Benthic mineralization rates at two locations in the southern North Sea. J Sea Res 36:181-191

Peeters JCH, Los FJ, Jansen R, Haas HA, Peperzak L, de Vries I (1995) The oxygen dynamics of the Oyster Ground, North Sea. Impact of eutrophication and environmental conditions. Ophelia 42:257-288

Pfannkuche O (1993) Benthic response to the sedimentation of particulate organic matter at the BIOTRANS station $47^{\circ} \mathrm{N}, 20^{\circ} \mathrm{W}$. Deep Sea Res 40:135-149

Puls W, Sündermann J (1990) Simulation of suspended sediment dispersion in the North Sea. In: Cheng RT (ed) Residual currents and long-term transport. Coastal and estuarine studies 38 . Springer, New York, p 356-372

Ridderinkhof $\mathrm{H}$ (1992) On the effects of variability in meteorological forcing on the vertical structure of a stratified watercolumn. Cont Shelf Res 12:25-36

Ruardij P, van Haren H, Ridderinkhof H (1997) The impact of timing of the thermal stratification on production succession and grazing of phytoplankton in shelf seas: a model study. J Sea Res (in press)

Sander BC, Kalff J (1993) Factors controlling bacterial production in marine and freshwater sediments. Microb Ecol 26:79-99

Simon M, Azam F (1989) Protein content and protein synthesis rates of planktonic marine bacteria. Mar Ecol Prog Ser 51:201-213

Sokal R, Rohlf FJ (1981) Biometry: the principles and practice of statistics in biological research. WH Freeman, San Francisco

Stauber JL, Jeffrey SW (1988) Photosynthetic pigments in fifty-one species of marine diatoms. J Phycol 24:158-172

Suess E (1980) Particulate organic carbon flux in the oceans: surface productivity and oxygen utilization. Nature 288:260-263

Sun MY, Lee C, Aller RC (1993a) Anoxic and oxic degradation of $14 \mathrm{C}$-labeled chloropigments and a $14 \mathrm{C}$-labeled diatom in Long Island Sound sediments. Limnol Oceanogr 38: $1438-1451$ 
Sun MY, Lee C, Aller RC (1993b) Laboratory studies of oxic and anoxic degradation of chlorophyll $a$ in Long Island Sound sediments. Geochim Cosmochim Acta 57:147-157

Sündermann J (1993) Suspended particulate matter in the North Sea: field observations and modelling. Phil Trans $R$ Soc Lond A. 343:45-52

Tett P. Walne A (1995) Observations and simulations of hydrography, nutrients and plankton in the southern North Sea. Ophelia 42:371-416

Thomsen L, Graf G, Von Juterzenka K, Witte U (1995) An in situ experiment to investigate the depletion of seston above an interface feeder field on the continental slope. Mar Ecol Prog Ser 123:295-300

Turley CM, Lochte K (1990) Microbial response to the input of fresh detritus to the deep-sea bed. Palaeogeogr Palaeoclimatol Palaeoecol 89:3-23

Van Duyl FC, Bak RPM, Kop AJ, Nieuwland G, Berghuis EM, Kok A (1992a) Mesocosm experiments: mimicking seasonal developments of microbial variables in North Sea sediments. Hydrobiologia 235/236:267-281

Van Duyl FC, Kop AJ (1994) Bacterial production in North Sea sediments: clues to seasonal and spatial variations. Mar Biol 120:323-337

Van Duyl FC, Kop AJ, Kok A, Sandee AJJ (1992b) The impact of organic matter and macrozoobenthos on bacterial and

Responsible Subject Editor: T. F. Thingstad, Roskilde, Denmark oxygen variables in marine sediment boxcosms. Neth J Sea Res 29:343-355

Van Duyl FC, van Raaphorst W, Kop AJ (1993) Benthic bacterial production and nutrient sediment-water exchange in sandy North Sea sediments. Mar Ecol Prog Ser 100:85-95

Van Haren JJM (1993) Theme I: Mooring. In: van Raaphorst W, Boon JP (eds) The integrated North Sea programme 1991-1992. Preliminary results. Neth Inst Sea Res Texel NL NIOZ Rep 1993-9:1-5

Van Raaphorst W, Malschaert JFP, Van Haren JJM (1997) Tidal resuspension and deposition of particulate matter in the Oyster Ground, North Sea continental shelf. J Mar Res (in press)

Verardo DJ, Froelich PN, Macintyre A (1990) Determination of organic carbon and nitrogen in sediments using the Carlo Erba Na-1500 analyser. Deep Sea Res 37:157-165

Walsh JJ, Whitledge TE, Barvenik FW. Wirick CD, Howe SO, Esaias WE, Scott JT (1978) Wind events and food chain dynamics within the New York Bight. Limnol Oceanogr 23:659-683

Wright SW, Jeffrey SW, Mantoura RFC, Llewellyn CA, Bjørnland T, Repeta D. Welschmeyer N (1991) Improved HPLC method for the analysis of chlorophylls and carotenoids from marine phytoplankton. Mar Ecol Prog Ser 77 . 183-196

Manuscript received: September 28, 1996

Revised version accepted: March 13, 1997 